\title{
Don Lindberg's Home Library and Leadership Traits
}

\author{
Robert A. Logan Ph.D. ${ }^{1}$ \\ U.S. National Library of Medicine (retired)
}

\begin{abstract}
This chapter introduces the importance and some of the multidisciplinary diversity in Donald A.B. Lindberg M.D.'s home library. The latter collection minimally suggests his varied interests, which often inspired a multidisciplinary approach to tackling problems and managing the U.S. National Library of Medicine (NLM). Dr. Lindberg converted the ideas he picked up from reading into administering projects as well as to set aspirational goals for NLM and for himself. The chapter suggests Dr. Lindberg's home library was an enduring reservoir of knowledge, judgment, planning, and creativity. The chapter also discusses two of Dr. Lindberg's leadership traits: the cultivation of discovery and project development in educational administration and the need for leaders to determine and act in the greater public interest. The chapter suggests the latter two traits defined Dr. Lindberg's NLM leadership.
\end{abstract}

Keywords. Donald A.B. Lindberg M.D., leadership, vision, administration, public interest, U.S. National Library of Medicine

\section{Introduction}

Honolulu's humidity was nearly incapacitating as Donald A.B. Lindberg M.D. and I waited in the cheerful home library of a Native Hawaiian physician. We were there to interview him for the National Library of Medicine's Native Voices exhibition in spring 2011 [1]. While our host was busy with a patient, Dr. Lindberg and I were grateful for a quiet moment in a pleasant setting with air conditioning. With a burst of enthusiasm and a bit of mischief, Dr. Lindberg said: 'let's peek at the bookshelves.'

As we perused, Dr. Lindberg kept calling me over to look at a volume of Hawaiian or Polynesian history. 'I've heard of this book, he exclaimed, never seen it.' Each new discovery provided an opportunity to be relished. After a few minutes, Dr. Lindberg said, 'This is as much fun as the Bishop museum.' He later told me his enthusiasm for the Native Voices project was so renewed by the experience (and a chance to cool off) that the subsequent interview became secondary.

Fittingly, a chapter of personal reflections about Dr. Lindberg's leadership and character should begin where his inspiration flourished - in his home library.

This chapter briefly introduces the importance of - and some of the multidisciplinary domains - in Dr. Lindberg's library. Building on its diversity as a managerial reservoir, the chapter discusses two of Dr. Lindberg's leadership traits: the cultivation of discovery

1 Corresponding author: logrob@gmail.com 
and project development in educational administration and the need for leaders to determine and act in the greater public interest.

\section{The Importance of a Home Library}

Turning first to Dr. Lindberg's home library, the collection minimally suggests his varied interests, which often inspired a multidisciplinary approach to tackling problems and managing the U.S. National Library of Medicine (NLM).

Don often told me the enduring impact of a well-chosen library was significantly greater than the sum of its parts. The process of reading triggered his thinking about how to address current challenges and often yielded imaginative ideas and approaches. $\mathrm{He}$ left notes to himself in some books that are windows into his thoughts at the time, which are noted in some cases below. To wit, Don's favorite bookmark translated the word 'think' into 22 languages including Chinese, Japanese, Hebrew, Greek, Arabic, and Hindi.

When appropriate, Don converted the ideas he picked up from reading widely into administering projects and often to set aspirational goals for NLM and for himself.

For example, Don began reading about the hokule'a (the Hawaiian language name for an indigenous ocean-capable catamaran) long before he launched the Native Voices project at NLM. The books he read suggested the hokule'a was an enduring sociocultural symbol of courage, applied intelligence, curiosity, progress, creativity, and wellbeing among Native Hawaiians [2]. His reading also suggested few persons outside of Polynesian and Native Hawaiian communities appreciated the hokulea's historical and contemporary socio-cultural significance.

With the latter understanding, Don insisted on meeting with some of the navigators (who reintroduced the hokule'a to contemporary Hawaii) during an initial 'Listening Circles' trip years before the Native Voices exhibition opened. (FYI: The navigators were the first 20th century Native Hawaiians to build a hokule'a using indigenous materials. At first, the navigators successfully sailed to Polynesian destinations and eventually they crossed some of the world's other oceans).

From his reading and preparation, Don gleaned that getting to know some navigators was as or more important than visiting with Native Hawaiian physicians, public health officials, healers, political leaders, and dignitaries. Don understood if Native Voices was going to be perceived as a constructive initiative by Native Hawaiians, a strong relationship needed to be established between NLM and Hawaii's hokule'a navigators (who included some dauntless physicians).

Eventually, Don arranged for a replica of a hokule'a to be built by Native Hawaiian crafts-persons. It was displayed for several years in the exhibit hall of NLM and eventually returned to Hawaii (in conjunction with the lifespan of the Native Voices exhibition). The exhibition also included paintings of historic and contemporary voyagers by the late Native Hawaiian artist Herb Kane. Parallel efforts occurred with Alaska Natives and some American Indian tribes to establish trust and enhance engagement. Some of the latter initiatives are detailed in other chapters in this book [3].

Yet, it was Don's extensive reading that helped him plan some of the elements within the Native Voices project. His preparation also provided a foundation to assess the advice he received from Native Hawaiian consultants. In Hawaii and elsewhere, Dr. Lindberg's home library was an enduring reservoir of knowledge, judgment, planning, and creativity. 


\section{The Topics in His Home Library}

Three of the most striking things about Dr. Lindberg's home library are: a) the volumes devoted to biomedical informatics and pathology (his clinical specialties) are significantly outnumbered by books about other sciences and the humanities; b) the collection's multidisciplinary range; and c) the books he authored/co-authored are hard to find.

Besides bioinformatics and pathology, the Lindberg library consists of topics that include: medical practice; history of medicine; history of science; science's social impact; higher education; the social impact of information technology; World War II; the U.S. Civil War; U.S. presidents; indigenous Americans; mass media; literature; opera; classical music; art; photography; children's stories; and travel and culture. Incidentally, the criteria to pick the latter topics was 10 or more books on the subject. Often, there were many more...

Briefly, in medical practice, the Lindberg library consists of often-consulted books about pathology, including Florey, General Pathology 4th and 5th edition and Anderson, Pathology, Volumes One and Two [4]. In biomedical informatics, the collection varies from books with a narrower focus, such as on nursing informatics, to broader research overviews. A 2006 biomedical informatics research roundup textbook begins: 'Dedicated to Donald A.B. Lindberg, whose innovative research and vision leadership of the National Library of Medicine have transformed both the field of biomedical informatics and the institution to which he has dedicated much of his professional life' [5]. The dedication is autographed by its co-authors, Ted Shortliffe M.D. and Jim Cimino M.D., who also provide significant contributions to the current book [6].

There is an extensive collection about the history of medicine. It includes a $20^{\text {th }}$ century book of Leonardo da Vinci's drawings of the human body - and da Vinci's signature is reproduced on the upper right corner of the second page [7]. The history of medicine collection includes a reprint by the New York Academy of Medicine of Morgagni's Seats and Causes of Disease (three volumes) that originally was published in 1769 [8]. There are several books about William Osler including both volumes of Cushing's biography [9]. Other histories about the life and contributions of leading physicians include books about John McGovern and by Bernadine Healy as well as books co-authored by Louis Sullivan M.D., who contributes the current book's foreword [10-13]. The history of medicine collection is supplemented by books about medical care during the U.S. Civil War and wilderness medicine. A book that Don kept close to his desk features French artist Honore Daumier's 19th century drawings about medical care, treatment, and physicians [14].

The Lindberg library's history of science collection includes several books about Charles Darwin as well as the books Darwin authored [15]. There is a half century old copy of The Double Helix and an original (and often-consulted) copy of Darcy Thompson's Growth and Form [16-17]. A coffee table book about landmarks of western science, published by the Library of Congress in 1987, features this inscription from its author Leonard Bruno: 'To Don with admiration for what he has done to perpetuate and enrich the traditions of science' [18].

The Lindberg library contains a spectrum of perspectives about science's social impact and includes books which represent diverse sides of 20th century debates about science and social progress. Some authors on the critical side, include C Wright Mills, Peter Berger, and Jacques Barzan. Writing in the mid-20th century, Barzan found science imposes itself as a single, deterministic mode of thought upon all experience - partially 
because of social inertia to counter its impact. Barzan was similarly critical of the arts [19].

Don writes at the end of a chapter where Barzan critiques modern art: 'art has stressed the bizarre to shock us ... this is ok - but modern art is bizarre in ways which mimic the sciences in point of view'... [19].

The Lindberg collection also contains C.P. Snow's book about the two cultures in higher education, which sparked a 20th century debate if the education of college students in the sciences or the humanities was so one-dimensional that it furnished a tacit risk to socio-cultural progress [20].

In contrast, some books in the Lindberg library (especially by Rene Dubos and Jacob Bronowski) note the constructive role of science in the creation of knowledge, the role of scientists in fostering a better quality of life, and furthering innovations and creativity in society and culture [21-22]. In Bronowski's book, The Origins of Knowledge and Imagination, Don underlines this passage: ' the most interesting thing about man is that he is an animal, who practices art and science and in every known society, practices both together [21].' Incidentally in this and other books, Bronowski criticizes some scientists Don respected including paleoanthropologists Konrad Lorenz and Robert Ardrey.

Environmental quality is the only scientific topic where a balance of perspectives is missing. The Lindberg library includes an earmarked copy of The Silent Spring and similar books about ecological decline [23]. In the Silent Spring's acknowledgements, Dr. Lindberg underlines: 'every writer of a book based on many diverse facts owes much to the skill and helpfulness of librarians' [23]. The acknowledgements go on to thank a librarian at the National Institutes of Health, which Don also underlines. Inside the book, Don inserted some clippings from the Wall Street Journal about the environmental harms of pesticide use.

Similar to most other areas, the Lindberg library features an admixture of critical and more favorable books about the goals of higher education and the impact of information technology on society. Some books, such as a late 20th century update to John Henry Newman's The Idea of a University, present a more favorable view than Snow regarding the socio-cultural impact of emphasizing degrees in professional and scientific training juxtaposed with liberal arts and general education [24]. Don left a bookmark and underlined parts of Newman's original preface where he notes the diffusion and extension of knowledge are as important as its advancement. The latter yields insights into Don's managerial vision to produce, diffuse, and extend biomedicine and biomedical informatics during his tenure as NLM's director. The latter efforts are detailed in the first three sections of this book and in the last section of this chapter.

Don's personal annotations fill his copy of Norbert Wiener's The Human Use of Human Beings: Cybernetics and Society [25]. In the book, Weiner suggests information technology is an extension of human intelligence. The book advances one of Don's core tenets regarding a computer's capacity to replace human judgment. Don often said the question is not whether computers can reason or create better than a human. To him (and to Wiener), the question was whether computers and a human do better than a person alone.

Yet, the extent of his underlining and accompanying notes suggest Don paid similar attention to Mowshowitz's sharp and prescient criticism of information technology (IT) that was published in 1976 [26]. For example, in a double underlined passage, Mowshowitz writes: 'The information processing model of man presupposes the intertranslatability of all modalities of experience, their distinctive formative principles being submerged in universal computational practices. So, we will have computer art, 
computer music, computer poetry, and what have you...' [26]. Mowshowitz adds: 'The computerized information processing system poses a challenge to the continued dominance of human intelligence in the control of human destiny' [26]. Don placed postit notes in the book to get quick access to both quotes and frequently wrote notes to himself throughout the book (both a rarity). The Wiener and Mowshowitz's books are accompanied by other volumes that reflect a range of differing viewpoints about IT, its future, and its ultimate impact on socio-cultural progress.

Otherwise, the Lindberg library features a considerable collection (more than 100 books) devoted to the history of World War II. The World War II collection features eight books about Charles de Gaulle and several books on the life and political career of Winston Churchill. Many of the latter books contain descriptions of the persistent frictions between the two leaders. The World War II collection is supplemented by several books written by Churchill and there is a separate collection that focuses on other $18-20^{\text {th }}$ century British history.

Don's interest in World War II is matched by his collection of books about the U.S. Civil War. There are 27 books about Civil War history on one shelf with a separate collection devoted to U.S. Presidents Lincoln and Grant.

The other U.S. presidents profiled in books within the Lindberg library include: Washington; Adams; Truman; Theodore Roosevelt; Franklin Delano Roosevelt; Clinton; and Obama. However, in terms of shelf space, no president compares to Thomas Jefferson. The Lindberg library includes a 20 -volume collection of Jefferson's writings published in 1903 [27]. This is supplemented by shelves of books about Jefferson's life, ideas, and work in all of its diverse capacities. I recall how enthusiastic Don was when NLM's History of Medicine Division consulted with the staff at Monticello (Jefferson's home) about how to visually display historical eras and timelines for the Native Voices exhibition.

The Lindberg library's collection of American history overviews features books by Henry Steele Commager, an Amherst professor who Don knew and admired.

A collection of biographies about American technological leaders includes: several books about Thomas Edison; Walter Isaacson's books about innovators; as well as his biography of Steve Jobs [28].

Returning to Don's interest in indigenous Americans, the Lindberg library includes books about Native Americans, Native Hawaiians, and Alaska Natives. For example, the books about Native American history and culture collection includes the Chief Joseph collection. Most of the books about Alaska Natives focus on their history and culture. As aforementioned, the books about Native Hawaiian history and culture skew towards the contemporary and historic efforts to voyage the Pacific Ocean. These include Heyerdahl's books about ocean expeditions and more recent sea voyaging/navigation mentioned previously [29]. Several books are devoted to the tragic history of Kalaupapa, the 19th-21st colony for Hansen's disease patients on the Hawaiian island of Molokai [30]. Don interviewed providers and patients on site in 2011 with the able assistance of a NLM videographer crew for the Native Voices exhibition. The latter is mentioned in chapters within the current book [3].

Yet, in another interesting (and apparently premeditated) juxtaposition, the collection about indigenous Americans is coupled with many books about the building of the U.S. Southwest and the 'Manifest Destiny' era of American life and culture. This includes a collection of novels by Zane Grey.

In terms of literature, the Lindberg library includes the works of Kipling, Thoreau, Faulkner, Tolstoy, Hawthorne, Shakespeare, and Benet among others. The poetry 
collection includes the works of Longfellow, Shelley, Dickinson, and Robert Frost (who Don met during his undergraduate days@ Amherst). While the Lindberg library emphasizes science and culture within the past two centuries, there is a collection of books about imperial Rome and ancient Greece.

Besides the arts, sciences, medicine, and culture, Don was interested in mass media practice and research. His collection about journalism and mass media includes books about Hearst, Sarnoff, Cronkite and by Lippmann, Friendly, Bradlee, Cronkite, Graham, Rooney, and Drew Pearson. (Don knew Drew Pearson, who is mentioned in the interview with Tyler Abell within the current book's memoirs, as well as Andy Rooney) [31].

The Lindberg library also features a complete collection of the books written by and about mass media scholar William Stephenson [32]. Stephenson, a faculty member in the Missouri School of Journalism in the 1960s-80s, was Dr. Lindberg's personal friend and colleague. Stephenson developed Q methodology, a mixed research method that enables an empirically grounded assessment of people's beliefs and attitudes (as opposed to the more conventional study of opinions). Q methodology influenced the development of psychographic analysis in advertising and strategic communication research.

For many years after Stephenson's death in 1989, Dr. Lindberg told me his awareness of the strengths and limitations of quantitative methods were influenced by Stephenson. Don hosted the annual research conference of the academic society that continues Stephenson's work @ NLM in 2007. During the conference, some NLM staff members who attended sessions frequently asked me: 'what does this have to do with bioinformatics or libraries?' I routinely responded: 'I promise you one thing; it all makes sense to Dr. Lindberg.'

The Lindberg home library also contains an array of books devoted to his hobbies, such as opera, classical music, art, photography, children's stories, as well as travel and culture.

The opera collection includes The Verdi Companion, and books about Madame Butterfly, Faust, Aida, 101 librettos, as well as biographies of divas and divos. These are accompanied by books that explore the impact of opera in society and culture. The classical music collection features several books about Mozart as a composer and a history of his life in Vienna. An often-perused three volumes of Shaw's music were placed near Don's desk so he could find them with a slight turn of his head to the left [33].

The Lindberg library includes books about the drawings/paintings and biographies of Matisse, Picasso, Renoir, and Norman Rockwell. (Don prized the Rockwell painting of small-town newsroom life that hangs in the National Press Club in downtown Washington and joked that seeing it was the best part of attending events there).

The Lindberg library contains a large collection (hundreds of books) about all aspects of photography. The books devoted to the work of specific photographers include: Karsh; Picker; Adams; the Westins (Brett and Edward); and Man Rey. There are books on photographic techniques, film developing, digital photo conversion, and the role of photography in society and culture. Don wrote more notes to himself within Susan Sontag's book about the cultural impact of photography than any I found within his library [34].

Two of the current book's memoirs note how much Don loved children's stories and the Lindberg library has a sizable collection [35]. One of Don's favorites was an original edition of Mabie's Fairy Tales Every Child Should Know (published in 1910) and Hero's Every Child Should Know - and there are collections of children's stories from the U.S., England, Ireland, Scotland, Canada, France, Sweden, and Japan [36]. 
There are collections about some of Don's other hobbies such as boating and bird watching.

Regarding travel, the Lindberg library contains guides and other books about the history of Greece, Italy, Jerusalem, Heidelberg, Scotland, the Bahamas, Santa Fe, and New Mexico's pueblos. Despite Don's seven decades of international and domestic travel, the largest cluster of books about a nation's culture, traditions, heritage, and history focus on Japan. Japan is one of the few destinations where used guidebooks were shelved. Don indirectly noted the Japanese influence on him once after finishing a series of exasperating meetings with peers from other U.S. federal health agencies. Knowing I sensed his funk following the experience, Don shook his head and said: 'sometimes, it helps to appreciate the Kubuki theater.' Incidentally, one well-worn guidebook is about Brooklyn, his hometown.

A few tidbits: I found the books Dr. Lindberg authored/edited on the bottom shelf of the last bookcase located on the least accessible side of his study. A few others are randomly scattered - and none receive prominent shelf space. The barely noticeable inclusion of his books suggests Don's process of self-discovery occurred by reading about other people, places, eras, and topics. The Lindberg library's raison d'être was not to rediscover his own work.

Some final thoughts: Don turned to books to help him stay abreast of science, biomedicine, and technological as well as a range of other domains. Simultaneously, Don embraced books that challenged conventional wisdom and added insights about the roles of science, medicine, bioinformatics, higher education, and the humanities in fostering or undermining social progress. Don was not one-dimensional in his reading; he read to supplement what he knew and challenge what he believed. Unlike most collections I have seen, the Lindberg library reflects more than disparate books about hobbies and professional interests. Books helped Don grow intellectually and served as a reservoir to ward off cognitive dissonance, or the tendency of some leaders to discredit conflicting evidence, reject contrary opinions, and reinforce what they believe [37]. In fact, some of the books Don collected noted the risks embedded in the latter character trait among leaders.

Overall, the Lindberg library was a foundation of Don's ability to lead, understand, contextualize, and renew. His reading was integral to the leadership traits discussed below.

\section{Dr. Lindberg's Leadership Traits - Cultivate Discovery and Innovation}

Building on the Lindberg library as a managerial reservoir, the chapter discusses two of Dr. Lindberg's leadership traits: the cultivation of discovery and innovation by administrators and the need for leaders to contemplate and act in the greater public interest.

Previously, I explained Dr. Lindberg's rare ability to breakdown his administrative vision into a series of specific projects [38]. Don could deconstruct macroscopic ideas into well-defined projects and implement them in a stepwise manner, which I suggested is a rare skill and was a key to his administrative success. As I wrote in 2019, visionaries are rarely adept at implementation and implementors are infrequently proficient at social and professional vision. Don could do both [38]. 
That said, the emphases here are two other traits that defined Don's NLM leadership, which may have been inspired by some of the aforementioned books in his library. This section begins with Don's interest in cultivating self-discovery and innovation. The next section is devoted to a discussion of his interest to act in the public interest.

I readily acknowledge that Don rarely discussed his managerial philosophy in public and to the best of my knowledge, he did not write about the topics covered in the remainder of this chapter. As a result, my comments and impressions are derived from the times he shared some of his ideas and thoughts in personal conversations. I also draw inferences from the books in the Lindberg library.

Perhaps the conversation where I learned the most about Don's philosophy about encouraging individual discovery and innovative research were his reactions to a meeting with a senior administrator at a large public U.S. university.

Towards the end of his NLM helm, Don and I were invited to speak to different schools within a university on the same day - and spend some time with a senior administrator. We looked forward to the trip because the senior administrator was early in his/her post and sought our feedback regarding the university's long range institutional plans. Don and I shared a prior interest in - and knowledge about - the university.

To provide some background, the senior administrator's career was exemplary; he/she was a productive scientist with often cited academic publications; an excellent track record of receiving sizeable grants and contracts; significant international scientific board service; and successful graduate student mentoring. The administrator had overseen an impressive increase in grants and contracts, overall fund raising, student enrollment, and international research recognition at a different Research 1 university. (Research 1 is a term that describes U.S. higher educational institutions that receive significantly more research grants and contracts than peer universities). Don knew the administrator slightly from participation in scientific societies.

I emphasize we approached our individual meetings with a genuine interest in the administrator's plans and success. Don and I agreed to exchange reactions the morning after our separate visits.

At breakfast, Don and I shared our impressions with sadness and dismay. Although the senior administrator was interpersonally collegial, he/she failed to comment favorably about anyone within the university's current academic leadership. In each of our separate conversations, the senior administrator refused to compliment or support the work of a dean, an individual faculty member, staff member, student, or even prominent alumni. Instead, the administrator sharply criticized some of the university's other leaders and researchers and discussed the superiority of colleagues at prior institutions all without prompting to do so. I told Don with some astonishment, 'I did not hear one nice word about anyone (at the current University).'

I added that I looked at PubMed, Google Scholar, nsf.gov, report.nih.gov, and a few other indexing services and found the University's recent track record of publications and grants seemed to challenge some of the senior administrator's claims.

In one of the rare times I ever heard Don deliver a soliloquy about leadership, he responded: 'The place is dying. A University (or any educational institution) cannot succeed if its leaders denigrate productive people. Instead, the boss needs to cultivate and appreciate. What bothers me is how (he/she) could forget this...'

Before he half-finished a glass of orange juice, Don explained the best way to manage a large educational institution was to cultivate employee discovery, provide the degrees of freedom talented people need to succeed, show interest but avoid micromanagement, and then, support as well as salute the ensuing efforts. 'You need to let 
people know you have their back to offset the criticisms that creative people often receive for their efforts,' he exclaimed.

Then, Don noted the need to provide research autonomy and degrees of freedom with support and without micro-management was especially important at the National Institutes of Health (NIH). Don explained NIH researchers were subject to comparatively strict mandates to deter employee conflict of interest. He continued that unlike university faculty, some top NIH researchers received annual third-party reviews of their external professional and community activities as well as their investments. In addition, Don noted NLM (similar to all NIH institutes) also required internal review prior to the refereed publication and conference submission of employee research. Since some of the latter requirements did not exist in research universities, Don remarked NIH's added burdens (coupled with comparatively less employee governance in the federal government) needed to be addressed by carefully creating a conducive atmosphere to support innovation and research.

Don explained an encouraging atmosphere partially was advanced by a series of strategies. Among other efforts these included: giving individuals sufficient time to conduct research; reducing non-research distractions; providing internal funds to support research; encouraging employee professional development; supporting travel to refereed conference presentation; encouraging expert collaboration and the diffusion of findings; hiring post-doctoral and other research fellows; bringing stimulating scholars to speak at NLM; and when possible, creating a family-like atmosphere. While these strategies may have been implemented differently within NLM's divisions, the chapters in the first three sections of this book attest that Don often succeeded in creating an institutional climate that supported individual and collaborative research, discovery, and innovation.

The chapters in the first three sections of this book (and the memoirs in this section by George Thoma, Randolph Miller, Rashid Bashshur, and Tom West) also suggest NLM developed an ethos during Don's watch that was guided by a sense of purpose to serve health care providers and later the public; develop fields (such as biomedical informatics and medical libraries); support intramural and extramural research; and even induce a positive social climate for collaboration and morale by hosting periodic dinners and events [39].

The chapters in the book's first three sections (and the aforementioned memoirs) add that NLM often was willing to advance technical innovation and stay ahead of the curve set by industry, universities, medical schools, and the federal government. The chapters note researchers intramurally and externally supported by NLM perceived they worked for an educational institution that was willing to lead to advance ideas while remaining mindful of the immediate and long-range interests of medical professionals, librarians, and eventually, the public. The chapters suggest NLM created an esprit de corps based on its supportive attitudes about research and researchers and a personal touch that included a genuine interest in a person's research and welfare, which were hallmarks of Don's administration and leadership.

Returning to the Lindberg library, many of the aforementioned books on the history of science and medicine directly or indirectly address how scientific and technological research thrives (or is compromised). Especially in The Ascent of Man, Bronowski noted that similar to the arts, science flourishes in an atmosphere where individual degrees of freedom, individual discovery, tolerance and diffusion are omnipresent [21]. Other authors, such as Dubos, make similar points, which are reinforced by books about the history of science's progress that were part of Don's collection [22]. While the latter books do not address administrative leadership, most embed counsel that scholarship is 
associated with a prevailing atmosphere that encourages academic values of independence, freedom to take risks, an ongoing curiosity, and an emphasis to support research activities.

I suggest Don's attitudes about good management were grounded in the latter values, which engendered a defining leadership trait.

Incidentally, while there was no record of campus unrest at the time of our meetings, Don gave the senior administrator 18 months before deans and senior faculty would demand an ouster. I was more pessimistic and predicted a change would happen within a year.

We were both wrong. The dismissal occurred seven months later - and was led by a coalition of deans, faculty, and students who represented all of the university's academic divisions. Three years after the breakfast, in a return to discuss our experience with the senior administrator, Don summarized: '(he/she) forgot about the need to support people, validate their curiosity, as well as the importance to create a vibrant institutional personality. The latter impacts morale and the zest with which people work, support others and the institution itself.'

\section{Stewardship, Education, Media, and a Public Interest Compass}

A related trait that impacted NLM's morale and characterized Don's leadership was his determination to act in the greater public interest and his commitment to use the Internet/World Wide Web for educational purposes. This section covers some of the origins and influences of Don's internal compass to act in the greater public interest in making administrative decisions.

To backup momentarily, I was a health-science journalist and launching a second career as a journalism professor/mass communication researcher when I met Don in 1977. For the next 42 years, we often discussed the leadership of journalists who balanced stakeholder versus the public interest (regardless of the policy issue at hand), the socio-cultural impact of mass media platforms, and the social responsibilities of the stewards of a new mass communication's medium (the Internet coupled with the World Wide Web). Don preferred to discuss the latter topics more than immediate issues of the day, our reactions to local, national, or international news, the actions of other leaders in government and industry, or personal matters. He joked that he could discuss biomedical informatics and clinical practice issues with the rest of his colleagues. Let's call it a dangling conversation that spanned five decades.

I was not surprised when my 2020 tour of the Lindberg library found books about journalism that discussed the profession's social responsibilities and profiled journalistic leadership as well as books and papers about the social impact of mass media and information technology. I introduced some of these books in this chapter's second section and will revisit a few of them here.

Indeed, the book Public Opinion by Walter Lippmann (published in 1922) is an enduring primer on public leadership and the advantages versus occasional risks of making decisions based on the greater public versus parochial interests [40]. Lippmann suggests a primary social responsibility of journalists (and leaders in any profession) is to balance stakeholder interests with broader public concerns. Lippmann suggests leaders should advance corrective action when decisions that impact communities, societies, and culture are grounded in more parochial than public concerns. The books about $20^{\text {th }}$ and 
$21^{\text {st }}$ century journalists that Don collected indirectly assess their leadership through Lippmann's framework. The biographies by or about Pearson, Bradlee, Friendly, Rooney, and Cronkite in the Lindberg library suggest how each responded to events and disclosed how stakeholders used power and influence to undermine, ignore, or advance the rights and concerns of most citizens [31]. The books note how these journalists saw their profession and job as an opportunity to lead by expanding social awareness and constructively influence public opinion.

Unsurprisingly, Don enjoyed conversations about news editors who sacrificed subscribers and revenues to pursue stories of community importance. Don especially liked hearing about John Seigenthaler and Gene Patterson, $20^{\text {th }}$ century U.S. journalism icons, who were the first news executives in Southern cities to lead a news organization's coverage of civil rights, race, and socio-economic disparities despite persistent and sometimes vitriolic community criticism or disinterest.

Yet I suggest Don's interest about journalism in conversations and books was to supplement leadership profiles about persons with the social awareness and dedication to act in the public interest - and the courage to commit despite socio-professional pressure and reproach. A similar leadership narrative undergirds some of the books he collected about American presidents, British prime ministers, and military decisionmakers during the U.S. Civil War. In contrast, some of the books he collected about Native Americans provide a counter narrative about the impact of leaders who lacked an awareness of humanitarian principles and made decisions based on more parochial interests.

Since the publication dates of the array of books about public leadership in the Lindberg library spans more than 60 years, the timeline (and the condition of the books on his shelves) suggests Don developed an interest in management within the public interest long before he became NLM's director in 1984.

Meanwhile, I suggest the following series of ideas - coupled with an opportunity to lead a federal health agency - combined to generate a sense of vision, purpose, and commitment, which became a foundation of Don's NLM leadership from 1984-2015.

By the mid-1970s Don had written about the potential of computers and information technology to impact medical research, medical knowledge, and medical practice [41]. As some other chapters in this book describe, Don was among the first to recognize that the diffusion of computing would have a transformative impact on medical professionals. However, these insights were just the start of his exposure to some related and transformative ideas that he began to consider.

For example, the books in the Lindberg library by Weiner and Mowshowitz (published in the mid-1970s) expanded the scope of the professional impact of computing to professions outside of science and medicine and noted the impact of the diffusion of computing on society and culture [25-26]. While the projected impact on major professions, society, culture, and science was perceived dissimilarly by Weiner and Mowshowitz, both books advanced the idea that information technology would impact the future of most aspects of human endeavors. As I mentioned previously, Don took notes and scribbled ideas in the margins and any available white space in the Weiner and Mowshowitz books, which suggests he was impressed by both. I suggest these and other writings (especially from Daniel Bell) broadened Don's perspective about the social and professional impact of computing. Don began to appreciate that the sociocultural impact of information technology was significantly more expansive than its bearing upon medical practice, research, and knowledge (which he previously described). 
Then, as Don began to ponder the wider social impact of IT, he was exposed for the first time to books and ideas about the long-term socio-cultural impact of mass media platforms on society. I am aware of the latter development because the topic was the basis of many conversations for more than four decades. Especially from 1978 to the mid-1980s, I was invited to lunch to discuss Innis, McLuhan, Carey, and Stephenson more than other professional or personal issues. Briefly, the Innis, McLuhan, and Carey thesis is the socio-cultural impact of public exposure to a mass media channel (such as print-based, audio-based, or video-based media) is far more profound than the content each medium provides. Innis, McLuhan, and Carey's ideas impressed Don, who found their implications intellectually compelling [42].

Since most of this book's readers do not have a mass communication research background, I will mention a little more about the core ideas that Don and I discussed because I believe they impacted his professional vision. I should add Don's initial interest in reading about the socio-cultural impact of mass media channels and platforms was inspired by his friend and colleague William Stephenson, whose scholarship touched on similar issues [32].

More specifically, Innis proposed changes in mass mediums or platforms from chiseled words to papyrus, hand-set, the Gutenberg press, linotype and mass-produced books and periodicals impacted pre- $20^{\text {th }}$ century society and culture more profoundly than the messages these printed and text-oriented mass mediums afforded [42]. Innis also noted the significant socio-economic, political, and cultural differences that occurred once societies transitioned from an oral to a written tradition as a primary means of mass communication and social learning.

I remember how interested Don was when he read McLuhan's interpretation of the social impact of television's introduction (as a mass medium or platform) because Innis provided a context to understand McLuhan's ideas. During the time he read both authors, Don mentioned he began to understand McLuhan's core arguments by contrasting the differences in how medical students raised during the television era learned compared to the pre-television generation. He often said to me that it was especially challenging to teach contemporary medical students because they learned more visually than their predecessors (which included his generation). 'I did not realize how confounding a challenge the radio generation (that Don experienced) must have been to my instructors.'

An essay by media scholar James Carey about the similarities and differences between Innis' and McLuhan's ideas prompted Don to exclaim for the first time in the early 1980s: 'I'm starting to appreciate that in the long run the (mass) medium may be the message [42].'

At this time, Don read a second essay from Carey that assessed the socio-cultural impact of the telegraph's introduction starting in 1848 [43]. Carey explains how the telegraph's unprecedented capacity to decode and transmit information did much more than enable $19^{\text {th }}$ century U.S. military commanders to stay in touch with presidents and send reports about news across town or to different cities (that prompted the parallel launch of the Associated Press). Carey explains that during its heyday as a technological innovation, the telegraph transformed how people perceived time and physical/geographical distance.

After reading Carey's essay, Don told me he interpreted it as suggesting how some of the major historical and geopolitical events from the mid- $19^{\text {th }}$ through the early $20^{\text {th }}$ century, such as wars and international colonialism, were impacted by the launch of a seemingly innocuous encode/decode technology, which accelerated the capability to efficiently exercise administrative control from a great distance. 
In turn, it did not take long for Don's new interest in the impact of mass media platforms to transform into a deeper understanding, enthusiasm, and accompanying concern about the growth of personal computing, networked computing, and the possibility of future public access to then-experimental World Wide Web. In conversations in the early 1980s, Don began to describe the convergence of personal computing, networked computers, and the then-hypothetical publicly accessible Web as a once in a lifetime opportunity - with an accompanying set of social responsibilities. 'Perhaps this time some leaders can get ahead of the curve,' he mentioned more than once.

In conversations, Don demonstrated his fresh understanding by questioning why some news organizations were interested in selling their news archives at a time when the then-experimental Web raised the unprecedented possibility for readers to have access to present combined with past news via then-nascent home and office desktop computers. He asked: 'Don't they (news executives) grasp what is coming?' Of course, the fact Don raised the question suggested he did....

Don also began to discuss the broader responsibilities, and the rare prospects, for persons in a position of leadership to recognize the implications of the birth and diffusion of a new mass communication's medium. 'Its best public use would be for educational purposes,' he said. 'Let's hope some leaders see the opportunity to establish an educational course before the new media's future as a profit center becomes evident....'

So, it was with historically significant timing (as fate may have it), that Don was appointed as NLM's director in 1984. Don's appointment occurred at the same time his understanding of mass media, information technology, and the need for leadership and stewardship were stimulated by a convergence of ideas and transformative events. Desktop and personal computers were starting to thrive, a new era of networked computing and connectivity was emerging, and the potential loomed for the experimental Internet and Web to provide much more than text and data.

Fortunately for Don, NLM already had an educational mission. NLM was committed to the collection and provision of medical information and literature mostly to healthcare providers via print and customer service platforms that served and collaborated with libraries and medical publishers across the U.S. and internationally. Additional interest was established in the use of innovative information technology to advance NLM's mission. Indeed, Don was one of the biomedical informatics' pioneers whom NLM supported. The challenge was to generate a sense of vision, purpose, and commitment regarding the use of new media technologies to assist medical professionals and concurrently, demonstrate how a new mass media platform could be put to its optimal public use.

A few weeks before Don officially became NLM's director an excited William Stephenson told me: 'now, we are really going to see something. Lindberg understands a new mass medium is emerging, its potential for educational purposes, and he will be in charge of a national health information institution with educational values. The synergy and timing could not be better.'

In terms of stewardship, Don brought to his new job the key understanding that mass media were an extension of human activity that could be put to their best use by enabling social and professional progress More specifically, Don understood a new mass medium's and emerging information technology's best uses were for educational purposes to: a) transform the ability of providers to obtain evidence-based medical information and $b$ ) organize health information so it could be optimized and accessed by 
utilizing a platform that enabled the transmission of data, text, photos, audio, video, data sets, with search capabilities (for the first time).

With this embedded context, the diverse and multidimensional projects described in this book are consistent with a larger educational, public, and professional service vision. The development of: MEDLINE; PubMed; PubMed Central; Clinicaltrials.gov, MedlinePlus.gov; UMLS; PubChem; Genetics Home Reference; Entrez; GenBank; NCBI Blast; Hazardous Substances Data Bank; Toxicology Data Network; support for electronic health records, expert systems, machine learning, medical libraries, and HighPerformance Computing and Communications; the Visible Human; Turning the Pages; as well as other information resources/services, other genetic surveillance platforms; outreach and educational programs for scientists, scientists, and the public are elements and extensions of a lofty plan.

The perseverance and mettle Don demonstrated by his support for NLM's educational projects and maximal public and professional access despite criticisms by diverse health care stakeholders (which is mentioned in several chapters in this book) suggest his commitment to educational values (based on the greater public interest) and the need to be a pioneering steward of a federal health agency and a new mass medium [44].

Don's challenge was to operationalize his vision, which began on the day of his appointment as NLM's director in a speech that set an agenda for the Library's immediate and long-range future [45]. Remarkably, Don remained focused on the optimal use of NLM's resources for educational and leadership purposes for the next 31 years. While it helped that Don had the simultaneous ability to perceive the forest, its trees and leaves, I suggest he would assert most of NLM's accomplishments were the result of the efforts of the Library's staff coupled with the evolution of research in biomedical informatics and associated scientific disciplines - with the cooperation of NLM's consultants and stakeholders.

I should add Don drew inspiration, guidance, and perhaps an ethical compass from Secretary John W. Gardner, U.S. Department of Health, Education and Welfare in the mid-1960s, who explained the differences between leadership and stewardship and implored persons in federal leadership to foster a more just society, promulgate educational values, act in the public's best interest, and remain tolerant of criticism and new ideas [46]. Don underlined many sections in Gardner's book about governance including this one: 'We don't need leaders to tell us what to do. That's not the American style of leadership in any case. We do need men and women in every community in the land who will accept a special responsibility to advance the public interest, root out corruption, combat injustice and care about the continued vitality of this land' [46, p. 134].

Otherwise, the current book attests how Don's leadership fostered an ethos that inspired many both inside and outside of NLM. I suggest his acumen was grounded by a converged vision that was sustained and cultivated by the ideas he gained from immediate colleagues as well as the authors and books that influenced him, which were parked on the ground floor of his personal library. It is a remarkable legacy I am grateful to recount. 


\section{Acknowledgement}

The access to Dr. Lindberg's home library and other contributions to this chapter by Mary Lindberg R.N. are gratefully acknowledged.

\section{References}

[1] https://www.nlm.nih.gov/nativevoices/index.html._Retrieved March 11, 2021.

[2] Low S. Hawaiki rising: Hokule'a, Nainoa Thompson, and the Hawaiian renaissance. Reprint ed. Honolulu: University of Hawaii Press; 2019. Lewis D, Oulton D. We the navigators: the ancient art of landfinding in the Pacific. $2^{\text {nd }}$ ed. Honolulu: University of Hawaii Press; 1994.

[3] Wood F, Altemus AR, Siegel ER. Native Voices exhibition: stories of health, wellness, and illness from American Indians, Alaska Natives and Native Hawaiians. In: Humphreys BL Logan RA, Miller RA, Siegel ER, editors. Transforming biomedical informatics and health information access: Don Lindberg and the U.S. National Library of Medicine. Amsterdam: IOS Press; 2021. Gottlieb K, Lindquist C, Mala TA, Mau MKLM. Reflections on Dr. Donald A.B. Lindberg and Native Voices. In: Humphreys BL, Logan RA, Miller RA, Siegel ER, editors. Transforming biomedical informatics and health information access: Don Lindberg and the U.S. National Library of Medicine. Amsterdam: IOS Press; 2021.

[4] Florey H, Florey B. General Pathology 4th and 5th Ed. Chicago, IL; 1970. Lloyd Luke; 1970. Kissane JM. Anderson's pathology. Ninth ed. St. Louis: CV Mosby; 1990.

[5] Ball MJ, Hannah KJ, Newbold SK, Douglas JV. Nursing informatics: computer applications in health care and biomedicine. New York: Springer; 2000. Shortliffe EH, Cimino JJ (Eds). Biomedical informatics: computer applications in health care and biomedicine. 3rd Ed. New York; Springer; 2006.

[6] Miller RA, Shortliffe EH. Donald A.B. Lindberg and the U.S. National Library of Medicine transformed biomedical and health informatics. In: Humphreys BL, Logan RA, Miller RA, Siegel ER, editors. Transforming biomedical informatics and health information access: Don Lindberg and the U.S. National Library of Medicine. Amsterdam: IOS Press; 2021. Cimino JJ. The biomedical informatics short course at Woods Hole/Georgia: training to support institutional change. In: Humphreys BL, Logan RA, Miller RA, Siegel ER, editors. Transforming biomedical informatics and health information access: Don Lindberg and the U.S. National Library of Medicine. Amsterdam: IOS Press; 2021. Amsterdam: IOS Press; 2021.

[7] O'Malley DC, Saunders JB de CM, editors. Leonardo da Vinci on the human body. New York: Harvey Schuman; 1952.

[8] Morgagni's Seats and Causes of Disease. New York Academy of Medicine (three volumes);

[9] Cushing H, The life of Sir William Osler. Oxford: Clarendon Press; 1925.

[10] Boutwell B. John P. McGovern: a lifetime of stories. College Station:Texas A\&M Press; 2014.

[11] Healy B. A new prescription for women's health: getting the best medical care in a man's world. New York: Viking Adult; 1995.

[12] Sullivan LW, Chanoff D. Breaking ground; my life in medicine. Athens, GA; University of Georgia Press; 2014.

[13] Sullivan LW. Foreward. In: Humphreys BL, Logan RA, Miller RA, Siegel ER, editors. Transforming biomedical informatics and health information access: Don Lindberg and the U.S. National Library of Medicine. Amsterdam: IOS Press; 2021Amsterdam: IOS Press, 2021.

[14] Adhemar J, Daumier H. Doctors and medicine in the works of Daumier. Boston: Boston Book and Art Shop; 1960. London edition Originally printed in 1769. Three volumes.

[15] Darwin C, Kebler L. On the origin of species by means of natural selection or, the preservation of favoured races in the struggle for life. London: J Murray; 1859. Darwin C. The descent of man and selection in relation to sex. London: British Library;1871. Francis KA. Charles Darwin and the origin of species. Westport CN: Greenwood Press; 2007.

[16] Watson JD. The double helix: a personal account of the discovery of the structure of DNA. London: Weidenfeld and Nicolson; 1981.

[17] Thompson D W. On growth and form. Cambridge: University Press; 1942.

[18] Bruno L. Traditions of science landmarks of western science in the collections of the Library of Congress. Washington, D.C.: U.S. Library of Congress; 1987.

[19] Barzan J. Science; the glorious entertainment. New York: Harper and Row; 1964.

[20] Snow CP. The two cultures and the scientific revolutions. New York: Cambridge University Press; 1959.

[21] Bronowski J. The origins of knowledge and imagination. New Haven: Yale University Press; 1979. Bronowski J. The ascent of man. Boston: Little Brown; 1973. 
[22] Dubos R. Quest: reflections on medicine, science, and humanity. New York: Harcourt Brace Jovanovich; 1980. Dubos R. So human an animal: how we are shaped by surroundings and events. New York: Scribner Book Company; 1998.

[23] Carson R. The silent spring. Cambridge, MA: The Riverside Press; 1962.

[24] Newman JH, Turner FM. The idea of a university. New Haven: Yale University Press, 1996.

[25] Wiener N. The human use of human beings: cybernetics and society. Garden City, NY: Doubleday; 1954.

[26] Mowshowitz A. The conquest of will: information processing in human affairs. Reading, MA: Addison Wesley; 1976.

[27] Jefferson T, Bergh AE. The writings of Thomas Jefferson. Washington, D.C.: Thomas Jefferson Memorial Association of the United States; 1903.

[28] Isaacson W. The innovators: how a group of hackers, geniuses, and geeks caused the digital revolution. New York: Simon \& Schuster; 2014. Isaacson W. Steve Jobs. New York: Simon \& Schuster; 2011.

[29] Heyerdahl T. American Indians in the pacific: the theory behind the kon-tiki expedition. London: George Allen \& Unwin; 1952. Heyerdahl T, The RA Expeditions, New York: Doubleday; 1971.

[30] Law AS. Kalaupapa: a collective memory. Honolulu: University of Hawaii Press; 2012.

[31] Logan RA. At Amherst and afterwards: interview with Tyler Abell about Don Lindberg. In: Humphreys BL Logan RA Miller RA, Siegel ER, editors. Transforming biomedical informatics and health information access: Don Lindberg and the U.S. National Library of Medicine. Amsterdam: IOS Press; 2021. Brinkley D. Cronkite. New York: Harper Collins; 2012. Cronkite W. A reporter's life. New York: Ballantine; 1997. Nasaw D. The chief: the life of William Randolph Hearst. Boston: Mariner Books; 2001. Bradlee B. A good life: newspapering and other adventures. New York: Simon \& Schuster; 1996. Graham K. Personal history. New York: Vintage; 1998. Friendly FW. Due to circumstances beyond our control. New York: Random House; 2013. Rooney A. Out of my mind. New York: PublicAffairs; 2006

[32] Stephenson W. The play theory of mass communication. Chicago: University of Chicago Press; 1967. Brown SR, Brenner DJ, editors. Science, psychology, and communication: essays honoring William Stephenson. New York: Teachers College Press; 1972

[33] Shaw B. Shaw's music: the complete musical criticism in three volumes. New York: Dodd, Mead; 1981.

[34] Sontag S. On photography. New York: Farrar, Straus and Giroux; 1977.

[35] Lindberg JEM. Memories of my father. In: Humphreys BL, Logan RA, Miller RA, Siegel ER, editors. Transforming biomedical informatics and health information access: Don Lindberg and the U.S. National Library of Medicine. Amsterdam: IOS Press; 2021. Lindbergh DAB. Learning from my dad: Donald A.B. Lindberg M.D. In: Humphreys BL, Logan RA, Miller RA, Siegel ER, editors. Transforming biomedical informatics and health information access: Don Lindberg and the U.S. National Library of Medicine. Amsterdam: IOS Press; 2021.

[36] Mabie HW. Editor. Famous stories every child should know. New York: Grosset \& Dunlap; 1907. Mabie HW. Editor. Fairy tales every child should know: a selection of the best fairy stories of all times and of all authors. New York Doubleday, Page \& Co.; 1905. Mabie HW. Editor. Heroes every child should know. New York Doubleday, Page \& Co.; 1906.

[37] Festinger L. A theory of cognitive dissonance. Evanston, IL.: Row, Peterson; 1957. Cooper J. Cognitive dissonance: 50 years of a classic theory. Newbury, CA: Sage; 2007.

[38] Logan RA. Remembering Don Lindberg: a transformative leader. https://www.healthaffairs.org/do/10.1377/hblog20190923.307979/full/ . Retrieved March 12, 2021.

[39] Thoma GR. Dr. Lindberg: an enduring source of inspiration. In: Humphreys BL, Logan RA, Miller RA, Siegel ER, editors. Transforming biomedical informatics and health information access: Don Lindberg and the U.S. National Library of Medicine. Amsterdam: IOS Press; 2021. Miller RA. Remembering Don Lindberg: two letters. In: Humphreys BL, Logan RA, Miller RA, Siegel ER, editors. Transforming biomedical informatics and health information access: Don Lindberg and the U.S. National Library of Medicine. Amsterdam: IOS Press; 2021. Bashshur RL. Don Lindberg's wisdom and influence: a personal perspective. In: Humphreys BL, Logan RA, Miller RA, Siegel ER, editors. Transforming biomedical informatics and health information access: Don Lindberg and the U.S. National Library of Medicine. Amsterdam: IOS Press; 2021. West TG. Donald A.B. Lindberg M.D., visual thinker and medical visionary. In: Humphreys BL, Logan RA, Miller RA, Siegel ER, editors. Transforming biomedical informatics and health information access: Don Lindberg and the U.S. National Library of Medicine. Amsterdam: IOS Press; 2021.

[40] Lippmann W. Public opinion. New York: Harcourt, Brace and Company; 1922.

[41] Lindberg DAB. The computer and medical care. Springfield, IL.: Thomas; 1968. Siler W, Lindberg DAB. Computers in life sciences research. New York: Plenum Press; 1975. Lindberg, DAB. The growth of medical information systems in the United States. Lexington, MA.: D.C. Heath and Company, Lexington Books; 1979.

[42] Innis HA. The bias of communication. Toronto: University of Toronto Press; 1964. Innis HA, Innis MQ. Empire and communications. Toronto: University of Toronto Press; 1972. McLuhan M. The Gutenberg 
galaxy; the making of typographic man Toronto: University of Toronto Press; 1962. McLuhan M. Understanding media: the extensions of man. New York: McGraw Hill; 1964. Carey, JW. Harold Adams Innis and Marshall McLuhan. The Antioch Review. 1967. 27(1), 5-39. doi:10.2307/4610816.

[43] Carey JW. Technology and ideology: the case of the telegraph. In: Carey JW. Communication as culture: essays on media and society. New York: Routledge; 1989. p. 201-230. Carey JW. Technology and ideology: the case of the telegraph. Prospects. 1983. 8, 303-325. DOI: 10.1017/S0361233300003793.

[44] Smith K. Free MEDLINE access for anyone with an Internet connection and a web browser. In: Humphreys BL, Logan RA, Miller RA, Siegel ER, editors. Transforming biomedical informatics and health information access: Don Lindberg and the U.S. National Library of Medicine. Amsterdam: IOS Press; 2021. Masys DR, Benson DA. Don Lindberg and the creation of the National Center for Biotechnology Information. In: Humphreys BL, Logan RA, Miller RA, Siegel ER, editors. Transforming biomedical informatics and health information access: Don Lindberg and the U.S. National Library of Medicine. Amsterdam: IOS Press; 2021. Mitchell JA. Donald A.B. Lindberg M.D. - my mentor. In: Humphreys BL, Logan RA, Miller RA, Siegel ER, editors. Transforming biomedical informatics and health information access: Don Lindberg and the U.S. National Library of Medicine. Amsterdam: IOS Press; 2021.

[45] https://collections.nlm.nih.gov/catalog/nlm:nlmuid-101629547-vid. Retrieved March 12, 2021.

[46] Gardner JW. No easy victories. New York: Harper \& Row; 1968. 